Article

\title{
PM2.5 Pollution in Xingtai, China: Chemical Characteristics, Source Apportionment, and Emission Control Measures
}

\author{
Jun $\mathrm{Hu}^{1,2}{ }^{1}$, Han Wang ${ }^{2,3}$, Jingqiao Zhang ${ }^{2,3}$, Meng Zhang ${ }^{2,3}$, Hefeng Zhang ${ }^{2,3,4, *}$, \\ Shulan Wang ${ }^{2,3, *}$ and Fahe Chai $2,3, *$ \\ 1 College of Water Sciences, Beijing Normal University, Beijing 100875, China; hujun@craes.org.cn \\ 2 Atmospheric Environment Institute, Chinese Research Academy of Environmental Sciences, Ministry of \\ Ecology and Environment (MEE), Beijing 100012, China; wh10901@163.com (H.W.); \\ zhangjq@craes.org.cn (J.Z.); zhangmeng@craes.org.cn (M.Z.) \\ 3 State Key Laboratory of Environmental Criteria and Risk Assessment, Chinese Research Academy of \\ Environmental Sciences, Beijing 100012, China \\ 4 National Joint Research Center for Tackling Key Problems in Air Pollution Control, Ministry of Ecology and \\ Environment (MEE), Beijing 100012, China \\ * Correspondence: zhanghf@craes.org.cn (H.Z.); wangsl@craes.org.cn (S.W.); Chaifh@craes.org.cn (F.C.); \\ Tel.: +86-105-0911-145 (H.Z. \& S.W. \& F.C.); Fax: +86-10-50911144 (H.Z. \& S.W. \& F.C.)
}

Received: 17 January 2019; Accepted: 28 February 2019; Published: 5 March 2019

\begin{abstract}
Beijing-Tianjin-Hebei (BTH) and its surrounding areas are one of the most polluted regions in China. Xingtai, as a heavy industrial city of BTH and its surrounding areas, has been experiencing a severe $\mathrm{PM}_{2.5}$ pollution in recent years, characterized by extremely high concentrations of $\mathrm{PM}_{2.5}$. In 2014, $\mathrm{PM}_{2.5}$ mass concentrations monitored by online instruments in urban areas of Xingtai were $116,77,128$, and $200 \mu \mathrm{g} \mathrm{m}^{-3}$ in spring, summer, autumn and winter, respectively, with annually average concentrations of $130 \mu \mathrm{g} \mathrm{m}^{-3}$ exhibiting 3.7 times higher than National Ambient Air Quality Standard (NAAQS) value for $\mathrm{PM}_{2.5}\left(35 \mu \mathrm{g} \mathrm{m}^{-3}\right)$. To identify $\mathrm{PM}_{2.5}$ emission sources, ambient $\mathrm{PM}_{2.5}$ samples were collected during both cold and warm periods in 2014 in urban areas of Xingtai. Organic carbon (OC), sulfate, nitrate, ammonium and elemental carbon (EC) were the dominant components of $\mathrm{PM}_{2.5}$, accounting for $13 \%, 11 \%, 12 \%, 11 \%$ and $8 \%$ in the cold period, respectively, and $11 \%, 12 \%$, $9 \%, 6 \%$, and $5 \%$ in the warm period, respectively. Source apportionment results indicated that coal combustion (24.4\%) was the largest $\mathrm{PM}_{2.5}$ emission source, followed by secondary sulfate $(22.2 \%)$, secondary nitrate $(18.4 \%)$, vehicle exhaust dust $(12.4 \%)$, fugitive dust $(9.7 \%)$, construction dust $(5.5 \%)$, soil dust (3.4\%) and metallurgy dust (1.6\%). Based on $\mathrm{PM}_{2.5}$ source apportionment results, some emission control measures, such as replacing bulk coal with clean energy sources, controlling coal consumption by coal-fired boiler upgrades, halting operations of unlicensed small polluters, and controlling fugitive and VOCs emission, were proposed to be implemented in order to improve Xingtai's ambient air quality.
\end{abstract}

Keywords: PM 2.5 Pollution; chemical characteristics; source apportionment; emission control measure; Xingtai

\section{Introduction}

Atmospheric particulate matter (PM) pollution has become a serious environmental problem in China, especially $\mathrm{PM}_{2.5}$ (particle matter with an aerodynamic diameter of less than or equal to $2.5 \mu \mathrm{m}$ ). $\mathrm{PM}_{2.5}$ is a complex mixture including both primary emissions and secondary formation, which mainly consist of organic carbon (OC) and elemental carbon (EC), sulphate, nitrate, ammonium, mineral 
dust, trace element and water etc. $\mathrm{PM}_{2.5}$ not only deteriorate regional and urban air quality [1-3], but also do harm to human health [4]. High concentrations of $\mathrm{PM}_{2.5}$ have a negative impact on public health and happiness. Exposure to high concentrations of $\mathrm{PM}_{2.5}$ has been recognized as a leading health risk factor in China [5] and across the world [6] in relation to cardiopulmonary morbidity and mortality. Increasing evidence suggests that chemical compositions in $\mathrm{PM}_{2.5}$ from different sources are responsible for adverse health effects. $\mathrm{PM}_{2.5}$ may be of natural or anthropogenic origin or both, which can be emitted directly into the atmosphere, or formed in the atmosphere by gaseous precursors, that is, $\mathrm{PM}_{2.5}$ is a mixture that can arise from multiple and complex sources. A clear understanding of major $\mathrm{PM}_{2.5}$ sources is the basis for formulating emission control measures [7].

Xingtai, located in the mid-southern area of the Beijing-Tianjin-Hebei (BTH) region, is an industrial city and is impacted by a combination of local and regional $\mathrm{PM}_{2.5}$ sources including coal-fired power plants, integrated steel plants, non-ferrous metals smelting, coking plants, manufacturing, motor vehicles, and secondary aerosols, etc. Along with rapid economic development and urbanization, $\mathrm{PM}_{2.5}$ pollution in urban area of Xingtai is rapidly increasing. Since 2005, coal consumption in Xingtai has increased dramatically and accounted for $16.6 \%$ of Hebei's total coal consumption in 2012, contributing to emissions of both primary $\mathrm{PM}_{2.5}$ and gaseous precursors of secondary $\mathrm{PM}_{2.5}$. In 2012, the Ministry of Environmental Protection (MEP) enacted the new National Ambient Air Quality Standards (NAAQS), which set $\mathrm{PM}_{2.5}$ guidelines for the first time of 75 and $35 \mu \mathrm{g} \mathrm{m}{ }^{-3}$ for daily and annual average values, respectively $[2,8]$. Since 2013, MEP began to report the top ten polluted cities in China. According to this report, in 2013 Xingtai ranked first in the top ten polluted cities [9]. In 2014, it ranked second [10]. In 2015, it still ranked second. Thus, it can be seen that Xingtai's air quality suffered from the worst $\mathrm{PM}_{2.5}$ pollution, which has been a tough environmental problem for local governments.

In 2013, MEP accelerates $\mathrm{PM}_{2.5}$ source apportionment to support policy making for air pollution prevention and control in China. MEP recommended two methods (i.e., source-oriented model and receptor model) to guild $\mathrm{PM}_{2.5}$ source apportionment and the combination of these two methods are encouraged to avoid the shortage of each method. Receptor models are generally used to quantitatively estimate pollutant levels contributed by different sources through statistical interpretation of ambient measurements. Among receptor models, chemical mass balance (CMB) is a source apportionment method to assess particle source contributions successfully, and has been widely applied in many different places around the world [11-14]. In 2014, Hebei's Environmental Protection Department (EPD) required all the 11 prefectural-level cities to perform $\mathrm{PM}_{2.5}$ source apportionment. Accordingly, Xingtai's Environmental Protection Bureau (EPB) started the project of $\mathrm{PM}_{2.5}$ source apportionment in order to effectively protect public health and implement emission reduction measures.

In this study, to obtain a better understanding of the chemical composition of Xingtai's $\mathrm{PM}_{2.5}$, identify emission sources of Xingtai's $\mathrm{PM}_{2.5}$, and formulate subsequent emission control measures, we carried out a comprehensive investigation about mass concentrations of $\mathrm{PM}_{2.5}$ (both on-line and off-line data), and the chemical composition of $\mathrm{PM}_{2.5}$ (OC and EC, water-soluble ions, and trace elements) for both cold and warm periods in 2014 in Xingtai. Furthermore, major emission sources of Xingtai's $\mathrm{PM}_{2.5}$ were identified and quantified by the $\mathrm{CMB}$ model. Based on source apportionment results, corresponding emission control measures were also proposed for improving Xingtai's air quality.

\section{Experimental Section}

\subsection{Sampling Site Description}

Xingtai is a medium-sized industrial city with some heavy industrial factories and is located on the mid-southern part of the Beijing-Tianjin-Hebei (BTH) Region, surrounded by Taihang Mountains in the west. The urban area is more than $162 \mathrm{~km}^{2}$, with a population of nearly 0.86 million. The prevailing wind is from the north and west during winter, and south during summer. The annual average wind speed is $\sim 1.5 \mathrm{~m} \mathrm{~s}^{-1}$. The average wind speed is $\sim 1.2 \mathrm{~m} \mathrm{~s}^{-1}$, and $\sim 1.5 \mathrm{~m} \mathrm{~s}^{-1}$ in winter and summer, 
respectively. The annual average static wind frequency is $15 \%$. Ambient $\mathrm{PM}_{2.5}$ samples were collected at six sites (NQ, DHQ, LQGS, HBJ, XSGZ, and SH) in Xingtai, as shown in Figure 1. The NQ site $\left(37^{\circ} 16^{\prime} \mathrm{N}, 114^{\circ} 30^{\prime} \mathrm{E}, 78 \mathrm{~m}\right)$ and $\mathrm{SH}$ site $\left(36^{\circ} 51^{\prime} \mathrm{N}, 114^{\circ} 30^{\prime} \mathrm{E}, 64 \mathrm{~m}\right)$ are located in north and south of urban areas, while the DHQ site $\left(37^{\circ} 05^{\prime} \mathrm{N}, 114^{\circ} 28^{\prime} \mathrm{E}, 71 \mathrm{~m}\right)$, LQGS site $\left(37^{\circ} 05^{\prime} \mathrm{N}, 114^{\circ} 31^{\prime} \mathrm{E}, 64 \mathrm{~m}\right), \mathrm{HBJ}$ site $\left(37^{\circ} 04^{\prime} \mathrm{N}, 114^{\circ} 28^{\prime} \mathrm{E}, 80 \mathrm{~m}\right)$ and $\mathrm{XSGZ}$ site $\left(37^{\circ} 02^{\prime} \mathrm{N}, 114^{\circ} 30^{\prime} \mathrm{E}, 67 \mathrm{~m}\right)$ are situated at urban areas of Xingtai. The six sampling sites are set on the rooftops of buildings that are approximately $9-15 \mathrm{~m}$ above ground level.

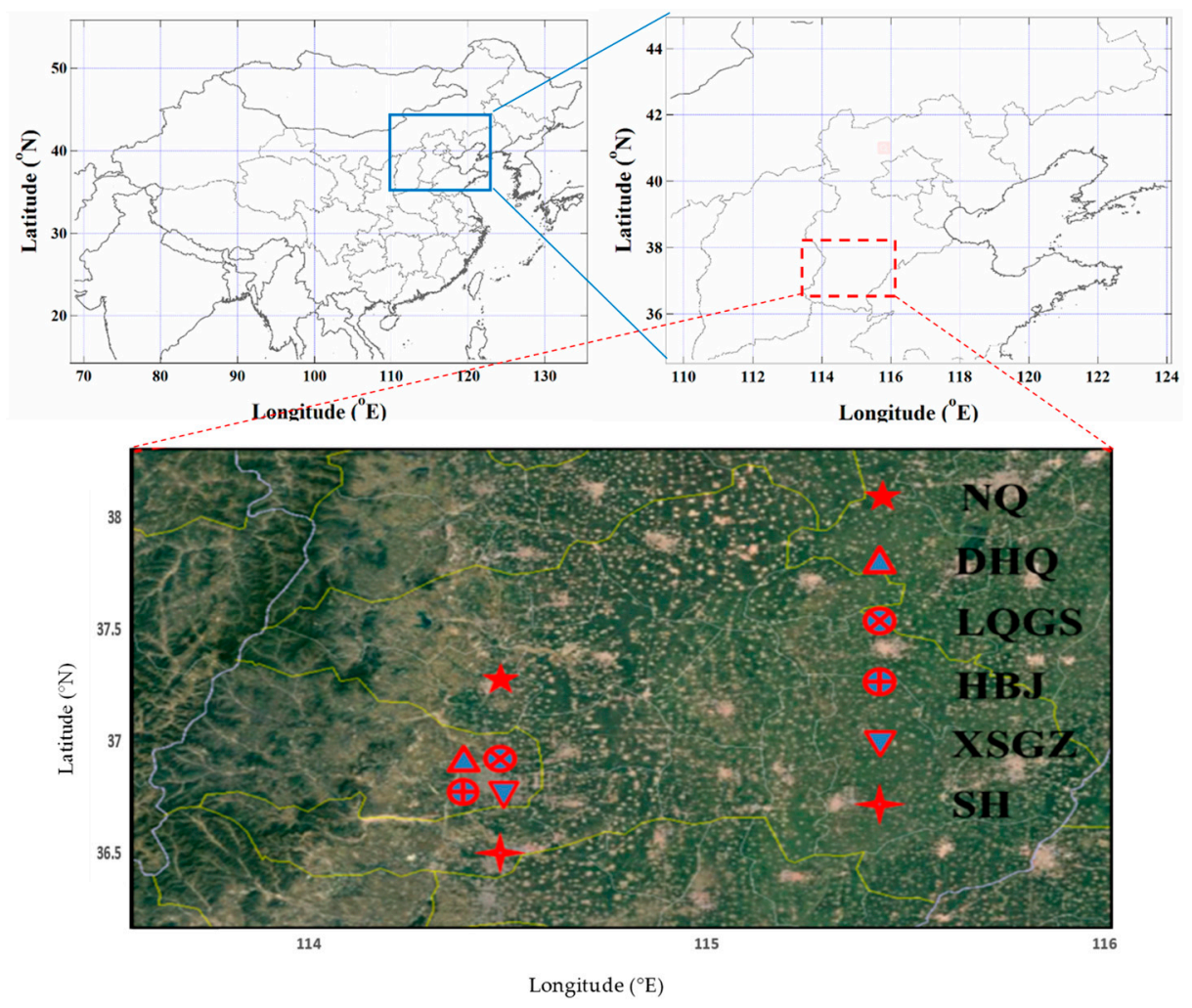

Figure 1. Location of the sampling sites in Xingtai.

\subsection{Sample Collection}

\subsubsection{Ambient Sample Collection}

$\mathrm{PM}_{2.5}$ ambient sampling was performed simultaneously at six sites of Xingtai City. The sampling time covered the cold (January and February) and warm (July and August) periods of 2014. Each sampling period was conducted continuously from $10 \mathrm{am}$ to $9 \mathrm{am}$ the next day. A four-channel sampler for PM (TH-16a, Tianhong Instruments Co., Ltd., China) with a flow rate of $16.7 \mathrm{~L} \mathrm{~min}^{-1}$ was employed to collect $\mathrm{PM}_{2.5}$. Teflon filters ( $47 \mathrm{~mm}$ in diameter) were used to collect samples for ion and elemental analysis and quartz filters ( $47 \mathrm{~mm}$ in diameter) were used to collect samples for organic carbon (OC) and elemental carbon (EC) analysis, respectively. A total of 236 and 240 valid ambient $\mathrm{PM}_{2.5}$ samples were collected in the cold and warm periods, respectively. Before and after sampling, Teflon-membrane filters were conditioned for $24 \mathrm{~h}$ at about $40 \% \mathrm{RH}$ and $25^{\circ} \mathrm{C}$ in an air-conditioned room and weighed on a microbalance with a resolution of $10 \mu \mathrm{g}$. Prior to sampling, the quartz filters were baked at $450{ }^{\circ} \mathrm{C}$ for $4 \mathrm{~h}$ to reduce blank carbon levels. OC and EC were determined by a thermal/optical carbon analyzer (DRI, Model 2001) using the IMPROVE protocol. The calibration of the analyzer was done before and after sample analysis every day. The background contamination was regularly monitored by blank tests, which were used to validate and correct the corresponding data. Blanks and duplicate sample analyses were conducted for nearly $10 \%$ of the samples. Certified reference materials (CRMs, produced by National Research Center for Certified Reference Materials, China) were used for quality control. 


\subsubsection{Source Sample Collection}

Due to the lack of local source profiles of major source types in Xingtai, such as coal combustion dust, typical industrial source, soil dust and road dust, some non-local source profiles were used in $\mathrm{PM}_{2.5}$ source apportionment work [14]. Based on the actual investigation of sources and the air pollution emission inventory from the official reports, major sources were identified, including representative industry dust such as chemical industry and metallurgical industry, coal combustion dust, construction dust, soil dust, road dust, fugitive dust, vehicle exhaust dust and secondary ionic particles. Samples of $\mathrm{PM}_{2.5}$ sources including chemical industry dust, metallurgical industry dust, coal combustion dust, construction dust, soil dust, road dust, fugitive dust were collected in Xingtai.

Representative industry dust and coal combustion dust were collected from particulate pollution control devices (electrostatic precipitators, fabric filters or wet scrubbers). Construction dust was collected from construction site and from production lines of nearby cement factories. Soil dust was collected from bare croplands or exposed land. Road dust was collected in the middle and on both sides of the road. Fugitive dust refers to dust that is continually raised into the surrounding atmosphere by natural forces or human activities, after being initially deposited in urban areas. The fugitive dust was collected on roofs of $20 \mathrm{~m}$ building using brooms or brushes. A total of 73 source samples were collected.

Following this, the collected dust samples were dried in a dark room with ventilation devices and sieved through 150 mesh sieves. The sieved material was then suspended in a resuspension chamber and sampled through size-selective inlets onto Teflon filters and quartz filters to obtain the $\mathrm{PM}_{2.5}$ samples used for analyses. This resuspension method has been used in pervious researches [15-17]. In addition, the source profile of vehicle exhaust was established from the source profile database of Environmental Protection Agency (SPECIATE 43). The chemical profiles of secondary sulfate and secondary nitrate were established according to the composition of pure $\left(\mathrm{NH}_{4}\right)_{2} \mathrm{SO}_{4}$ and $\mathrm{NH}_{4} \mathrm{NO}_{3}$.

\subsubsection{Other Pollutants}

The concentrations of gas pollutants, including $\mathrm{NO}_{2}, \mathrm{SO}_{2}, \mathrm{PM}_{2.5}$ and $\mathrm{PM}_{10}$, were recorded at one-hour intervals by the air quality monitoring stations located at the sampling sites belonging to the Ministry of Environmental Protection in China.

\subsection{Chemical Analysis}

Prior to extraction and digestion, each Teflon-membrane filter was cut into two equal halves with ceramic scissors. One half was subjected to Milli-Q water extraction for ionic measurement and the other half to acid digestion for elemental measurement. For acid digestion, the polypropylene support O-ring on half of each filter sample was carefully removed with a ceramic knife to avoid contamination. The filter samples were digested with an acid mixture by using an ultrahigh throughout microwave digestion system (MARSXpress, CEM, Matthews, NC). A blank reagent and two filter blanks were prepared in each run following the same procedure used for the samples. All the acids used in this study were of ultra-pure grade (Merck, Germany). The detailed digestion method has been published elsewhere [18]. Another half of all filter samples were used for extraction with $20 \mathrm{~mL}$ Milli-Q purified water (specific resistivity $=18.2 \mathrm{M} \Omega \mathrm{cm}^{-1}$; Millipore, Massachusetts, USA) for $1 \mathrm{~h}$. The detailed extraction procedures have been described in Hsu et al. [19,20].

Water-soluble ions $\left(\mathrm{NO}_{3}{ }^{-}, \mathrm{SO}_{4}{ }^{2-}, \mathrm{Cl}^{-}, \mathrm{NH}_{4}{ }^{+}, \mathrm{K}^{+}, \mathrm{Ca}^{2+}, \mathrm{Na}^{+}, \mathrm{Mg}^{2+}\right)$ were analyzed by ion chromatography (Met-820, Metrohm). In general, the method detection limits (MDLs) were within the range of 0.01 to $0.04 \mu \mathrm{g} \mathrm{m}^{-3}$ for cations and 0.03 to $0.07 \mu \mathrm{g} \mathrm{m}^{-3}$ for anions [19]. One half of each Teflon-membrane filter was put into a glass tube and deionized water was used to extract. The extraction procedure was conducted for at least three times so that the water-soluble ions of samples were extracted adequately into the solution. Before ions detection, standard solutions were prepared and were detected for over three times, and low relative standard deviations were observed. 
A range of elements $(\mathrm{Na}, \mathrm{K}, \mathrm{Si}, \mathrm{Ca}, \mathrm{Mg}, \mathrm{Al}, \mathrm{Ti}, \mathrm{V}, \mathrm{Cr}, \mathrm{Mn}, \mathrm{Fe}, \mathrm{Ni}, \mathrm{Cu}, \mathrm{Pb}, \mathrm{Ba}, \mathrm{Sn}, \mathrm{Cd}, \mathrm{Se}, \mathrm{As}$ and $\mathrm{Zn}$ ) were analyzed by inductively coupled plasma-mass spectrometry (ICP-MS) (XSeries 2, Thermo Fisher) [21,22]. Before being measured by ICP-MS, the other half of each Teflon-membrane filter was cut into fragments and placed into a conical flask. Acid solutions $\left(15 \mathrm{~mL}\right.$ of $\mathrm{HNO}_{3}$ and $5 \mathrm{~mL}$ of $\mathrm{HClO}_{4}$ ) were added into the flask and the flask was heated by electric stove. The solution was evaporated until about $3 \mathrm{~mL}$ residual was left. After being cooled and filtered, the solution was decanted into a test tube and diluted to $15 \mathrm{~mL}$ with deionized water. An alkali solution was used for measuring the concentrations of silicon. For quality assurance and quality control (QA/QC), standard reference materials were pre-treated and analyzed with the same procedure, with the recovered values for all the target elements falling into the range or within $5 \%$ of certified values.

A punch of $0.526 \mathrm{~cm}^{2}$ from each quartz filter was heated stepwise by a thermal/optical carbon analyzer (DRI 2001, Atmoslytic, US) in a pure helium atmosphere at $140{ }^{\circ} \mathrm{C}(\mathrm{OC} 1), 280{ }^{\circ} \mathrm{C}(\mathrm{OC} 2)$, $480{ }^{\circ} \mathrm{C}(\mathrm{OC} 3)$, and $580^{\circ} \mathrm{C}(\mathrm{OC} 4)$, and then in $2 \% \mathrm{O}_{2}$ and $98 \%$ He atmosphere at $580{ }^{\circ} \mathrm{C}(\mathrm{EC} 1), 740{ }^{\circ} \mathrm{C}$ (EC2), and $840{ }^{\circ} \mathrm{C}$ (EC3) to convert any particulate carbon on the filter to $\mathrm{CO}_{2}$. After being catalyzed by $\mathrm{MnO}_{2}, \mathrm{CO}_{2}$ was reduced to $\mathrm{CH}_{4}$, which was then directly measured. Mass concentrations of $\mathrm{OC}$ and EC were obtained according to the IMPROVE protocol [23] $(\mathrm{OC}=\mathrm{OC} 1+\mathrm{OC} 2+\mathrm{OC} 3+\mathrm{OC} 4+\mathrm{OP}$; $\mathrm{EC}=\mathrm{EC} 1+\mathrm{EC} 2+\mathrm{EC} 3-\mathrm{OP}$, where OP is the optical pyrolyzed OC). Detailed descriptions can be found in Zhang et al. [24].

\subsection{CMB Analysis and Source Identification}

The CMB is a single-sample receptor model that can be stated in terms of the contribution from $p$ independent sources to all chemical species as follows:

$$
x_{i j}=\sum_{k=1}^{p} g_{i k} f_{k j}+e_{i j}
$$

where $x_{i j}$ is the measured concentration of species $j$ in sample $i, f_{k j}$ is the concentration of species $j$ in the emissions of source $k, g_{i k}$ is the contribution of source $k$ to sample $i$, and $e_{i j}$ is the model residual. This model considers a prior knowledge of the source profiles and that the components of the source emissions do not undergo changes during their transport from the source to the receptor. $\mathrm{CMB}$ provides an effective variance-weighted least-squares solution to the overdetermined set of mass balance equations. CMB takes into account the known uncertainties in the ambient measurements and the source emission data to minimize the chi-square $\left(x^{2}\right)$ goodness-of-fit parameter for each sample $i$ :

$$
x^{2}=\sum_{j=1}^{m}\left[x_{j}-\sum_{k=1}^{p} g_{j k} f_{k} / \sigma_{x_{j}}^{2}+\sum_{k=1}^{p} \sigma_{g_{j k}} f_{k}\right]
$$

where $\sigma_{x_{j}}$ is the standard deviation of the concentration of species $j, \sigma_{g_{j k}}$ is the standard deviation of the $g_{j k}$, and $m$ is the total number of species. The US EPA-CMB8.2 software has been successfully used to apportion source contributions to ambient $\mathrm{PM}_{2.5}$ [25-30] and was also used in the current study. More details about CMB can be found elsewhere [12,31].

Eight source categories were identified, including construction dust, coal combustion, metallurgical dust, road dust, fugitive dust, soil dust, vehicle exhaust dust, secondary sulfate and secondary nitrate. Since CMB does not distinguish secondary sources, "pure" sulfate (contains only $72.7 \%$ sulfate ion in $\left(\mathrm{NH}_{4}\right)_{2} \mathrm{SO}_{4}$ ) and "pure" nitrate (contains only $77.5 \%$ nitrate ion in $\mathrm{NH}_{4} \mathrm{NO}_{3}$ ) are assumed as secondary sources in the source profile. As a result, the method identifies the contribution of gas-to-particle formation [32]. In total, 476 samples consist of 8 water-soluble ions, 16 chemical elements, $\mathrm{OC}$ and EC were used in the source apportionment.

It should be noted that source profiles of fugitive dust and soil dust shared similar major components, as shown in Section 3.3. However, traditional CMB model is sensitive to collinearity 
problem among source profiles, which may result in unreliable information. As a kind of mixed source, fugitive dust is composed of a mixture from each single dust source. Therefore, fugitive dust can be considered as the source of $\mathrm{PM}_{2.5}$ in the ambient air and can be regarded as the receptor of $\mathrm{PM}_{2.5}$ of each single dust source. Thus, according to the principle of chemical mass balance, the CMB model can be used to calculate the contribution of each single dust source to fugitive dust. In this research, fugitive dust was calculated both as source and as receiver to improve the CMB model.

First of all, the CMB model was used to calculate the contribution of each individual primary source. Secondly, the fugitive dust was considered as a receptor and the contribution of each individual primary source to fugitive dust was calculated. Thirdly, the contribution of fugitive dust to ambient $\mathrm{PM}_{2.5}$ was calculated. Finally, by incorporating the results from this three-stage modeling approach, the collinearity-controlled net contribution from each source was obtained. Further details about the improved CMB model have been previously described [17].

\section{Results and Discussions}

\subsection{Levels of $P M_{2.5}$ Mass Concentrations in Xingtai}

$\mathrm{NO}_{2}$ and $\mathrm{SO}_{2}$ - gaseous precursors of secondary $\mathrm{PM}_{2.5}$ - were the main contributors for ambient $\mathrm{PM}_{2.5}$ formation. Annual average concentrations of $\mathrm{NO}_{2}, \mathrm{SO}_{2}, \mathrm{PM}_{2.5}$ and $\mathrm{PM}_{10}$ and the ratio of exceeding Chinese NAAQS guidelines in Xingtai are shown in Figure 2. Annual average levels of $\mathrm{NO}_{2}, \mathrm{SO}_{2}, \mathrm{PM}_{2.5}$ and $\mathrm{PM}_{10}$ were $61,76,130$, and $233 \mu \mathrm{g} \mathrm{m}{ }^{-3}$, respectively. It can be seen from Figure 2 that $\mathrm{PM}_{2.5}$ had exceeded by 2.71 times the Chinese NAAQS values of $35 \mu \mathrm{g} \mathrm{m}{ }^{-3}$ for $\mathrm{PM}_{2.5}$, and $\mathrm{PM}_{10}$ had exceeded by 2.33 times the Chinese NAAQS values of $70 \mu \mathrm{g} \mathrm{m}^{-3}$ for $\mathrm{PM}_{10}$, respectively. Thus, it can be ascertained that $\mathrm{PM}_{2.5}$ was the first primary pollutant in Xingtai because the ratio by which it exceeded guideline levels of $\mathrm{PM}_{2.5}$ was the highest. In 2014, in addition to Baoding $\left(162 \mu \mathrm{g} \mathrm{m}^{-3}\right)$, Xingtai ranked second in $\mathrm{PM}_{2.5}$ levels in Hebei Province, which was slightly higher than Shijiazhuang $\left(124 \mu \mathrm{g} \mathrm{m}^{-3}\right)$ [10]. Therefore, Xingtai's $\mathrm{PM}_{2.5}$ pollution has been an extremely serious environmental problem, which placed tremendous stress on local governments.

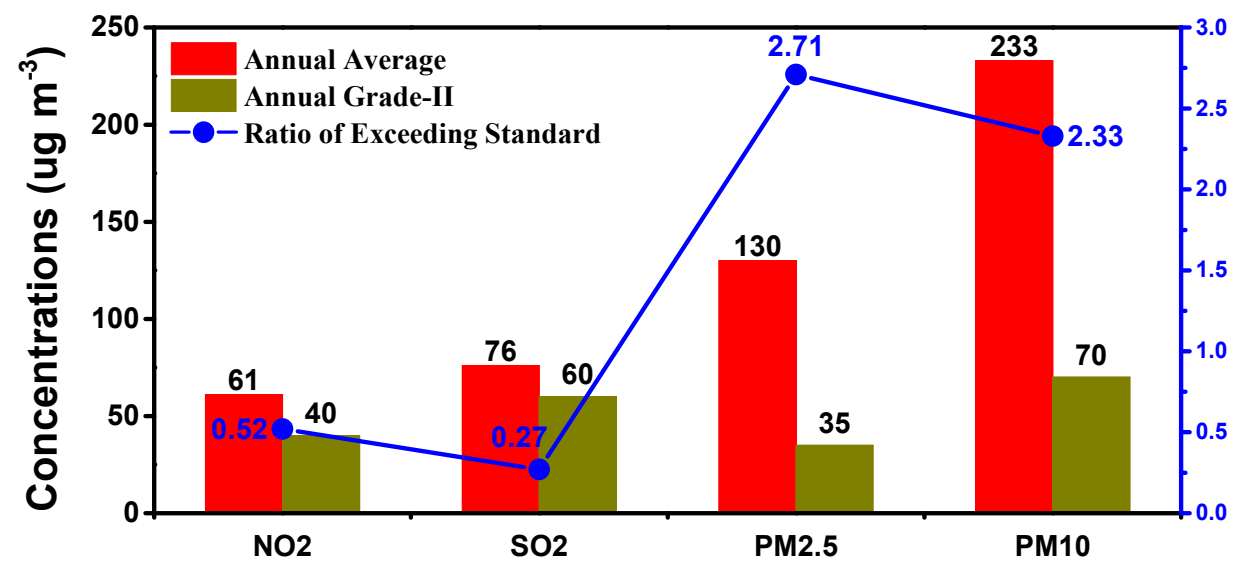

Figure 2. Annually average value of $\mathrm{NO}_{2}, \mathrm{SO}_{2}, \mathrm{PM}_{2.5}$ and $\mathrm{PM}_{10}$ and the ratio by which they exceeded Chinese NAAQS guidelines (2014, on-line data).

Xingtai's $\mathrm{PM}_{2.5}$ and $\mathrm{PM}_{10}$ mass concentrations from January 2014 until December 2014 were monitored by on-line instruments and are shown in Figure 3. Clear seasonal variation in $\mathrm{PM}_{2.5}$ mass concentrations can be observed, with a high concentration of $200 \mu \mathrm{g} \mathrm{m}^{-3}$ in winter (December-February) and a low concentration of $77 \mu \mathrm{g} \mathrm{m}^{-3}$ in summer (June-August), respectively. $\mathrm{PM}_{10}$ had the same seasonal characteristics as $\mathrm{PM}_{2.5}$, with a high concentration of $325 \mu \mathrm{g} \mathrm{m}^{-3}$ in winter and a low concentration of $138 \mu \mathrm{g} \mathrm{m}^{-3}$ in summer. High $\mathrm{PM}_{2.5}$ mass concentrations in winter might be closely related to both lots of continued local pollutant emissions and adverse meteorological condition (such as high $\mathrm{RH}$ and temperature inversion). Low $\mathrm{PM}_{2.5}$ mass concentrations in summer were partly 
due to frequent precipitation events and favorable atmospheric diffusion, which led to efficient removal of particles from the atmosphere. In China, heavy pollution episodes often happen in autumn and winter and can be classified into two types: (1) An explosive growth of $\mathrm{PM}_{2.5}$ within a few hours; (2) and a continuous increase of $\mathrm{PM}_{2.5}$ in several days [2]. For instance, from January 12 to January 16, $\mathrm{PM}_{2.5}$ mass concentrations in Xingtai showed a continuous increase and the peaking concentrations were $606 \mu \mathrm{g} \mathrm{m}^{-3}$, which were 8 times higher than that $\left(75 \mu \mathrm{g} \mathrm{m}^{-3}\right.$ for $\left.\mathrm{PM}_{2.5}\right)$ of Chinese NAAQS.

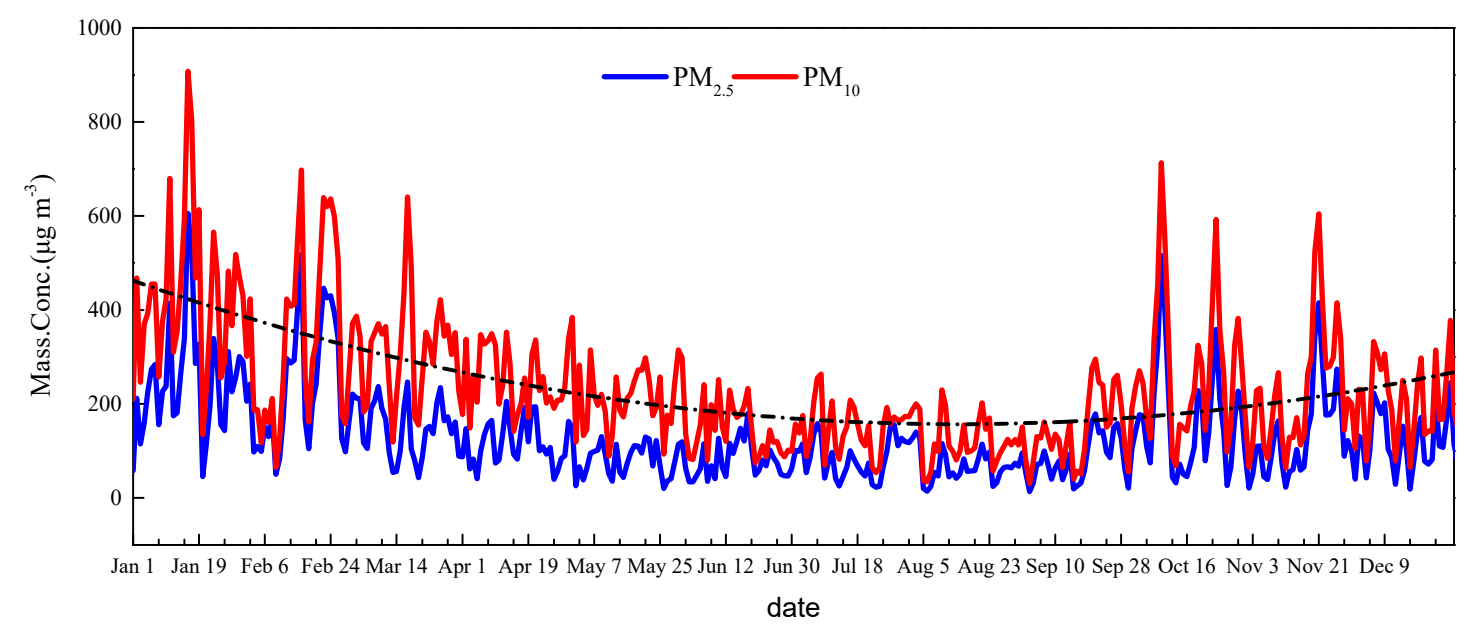

Figure 3. $\mathrm{PM}_{2.5}$ and $\mathrm{PM}_{10}$ mass concentrations from January 2014 to December 2014 (on-line data).

\subsection{Chemical Composition of $P M_{2.5}$}

In total, 236 and 240 valid ambient $\mathrm{PM}_{2.5}$ samples were collected in cold and warm periods, respectively. $\mathrm{PM}_{2.5}$ mass concentrations (off-line data, filter-based), and organic carbon (OC), elemental carbon (EC), water-soluble inorganic ions (WSIIs), and trace elements for both cold and warm periods in Xingtai are listed in Table 1. The time series of major $\mathrm{PM}_{2.5}$ components for cold and warm periods are shown in Figure $4 \mathrm{a}, \mathrm{b}$, respectively. $\mathrm{PM}_{2.5}$ mass concentrations in Xingtai ranged from 66.73 to $458.48 \mu \mathrm{g} \mathrm{m}^{-3}$ with an average of $214.53 \pm 87.46 \mu \mathrm{g} \mathrm{m}^{-3}$ in the cold period, and changed from 13.19 to $121.38 \mu \mathrm{g} \mathrm{m}^{-3}$ with an average of $81.43 \pm 35.08 \mu \mathrm{g} \mathrm{m}^{-3}$ in the warm period. The average concentrations were over 6 and 2 times higher than Chinese NAAQS values for $\mathrm{PM}_{2.5}\left(35 \mu \mathrm{g} \mathrm{m}^{-3}\right)$, respectively. It can be seen in Table 1 that the $\mathrm{PM}_{2.5}$ level for the cold period was approximately 3 times higher than that of the warm period in Xingtai.

The average OC and EC concentrations were $27.32 \pm 17.82$ and $16.18 \pm 9.53 \mu \mathrm{g} \mathrm{m}^{-3}$ for the cold period and $9.13 \pm 2.60$ and $4.40 \pm 2.32 \mu \mathrm{g} \mathrm{m}^{-3}$ for the warm period, respectively. The average WSII concentrations were 82.86 and $27.72 \mu \mathrm{g} \mathrm{m}^{-3}$ for the cold and warm periods, respectively. Sulfate $\left(\mathrm{SO}_{4}{ }^{2-}\right)$, nitrate $\left(\mathrm{NO}_{3}{ }^{-}\right)$, and ammonium $\left(\mathrm{NH}_{4}{ }^{+}\right)$(denoted by SNA) were the major contributors to WSIIs, accounting for $88.2 \%$ and $79.8 \%$ for the cold and warm periods, respectively. SNA are mainly formed from gaseous precursors $\left(\mathrm{SO}_{2}, \mathrm{NOx}\right.$, and $\left.\mathrm{NH}_{3}\right)$ through complicated gas- and aqueous-phase chemical reactions. The concentrations of SNA were higher for the cold period than the warm period. The possible explanation for this result may be extra coal combustion for resident heating, or synthetic action of between $\mathrm{SO}_{2}, \mathrm{NOx}$ and $\mathrm{NH}_{3}$ emissions and heterogeneous reactions, or unfavorable meteorological conditions. It can be seen in Table 1 that $\mathrm{OC}, \mathrm{EC}, \mathrm{SO}_{4}{ }^{2-}, \mathrm{NO}_{3}{ }^{-}$, and $\mathrm{NH}_{4}{ }^{+}$were the dominant components, accounting for $59 \%$ of $\mathrm{PM}_{2.5}$ for the cold period and $39 \%$ of $\mathrm{PM}_{2.5}$ for the warm period. Trace elements play an important role in emission source estimation and are associated with coal combustion, industrial process, traffic, and residential activities. For instance, crustal elements, such as $\mathrm{Si}, \mathrm{Al}, \mathrm{Mg}, \mathrm{Ca}$, and $\mathrm{Ti}$, are associated with fugitive dust [33]. $\mathrm{Pb}$ is discharged from the smelting and coal combustion processes [34], and $\mathrm{Cd}, \mathrm{Mo}, \mathrm{Cu}$, and $\mathrm{Ba}$ are generated by motor vehicle emissions [35]. For trace elements, the relatively high concentrations of trace elements are in the order 
of $\mathrm{Si}>\mathrm{Al}>\mathrm{K}>\mathrm{Fe}>\mathrm{Zn}>\mathrm{Pb}>\mathrm{Mn}>\mathrm{Ti}$, with $99.3 \%$ and $99.1 \%$ of total element mass contributions for the cold and warm period, respectively.

Table 1. Mass concentrations of $\mathrm{PM}_{2.5}$ and levels of OC, EC, ions, and trace elements for all sites in the cold and warm periods (off-line data, data derived from filter membrane sampling analysis).

\begin{tabular}{|c|c|c|c|c|}
\hline \multirow[t]{2}{*}{ Species } & \multicolumn{2}{|c|}{$\begin{array}{c}\text { Cold Period } \\
\left(\mu \mathrm{g} \mathrm{m}^{-3}\right)(n=236)\end{array}$} & \multicolumn{2}{|c|}{$\begin{array}{c}\text { Warm Period } \\
\left(\mu \mathrm{g} \mathrm{m}^{-3}\right)(\mathrm{n}=240)\end{array}$} \\
\hline & Ave. & SD & Ave. & SD \\
\hline $\mathrm{PM}_{2.5}$ & 214.53 & 87.46 & 81.43 & 35.08 \\
\hline $\mathrm{EC}$ & 16.18 & 9.53 & 4.40 & 2.32 \\
\hline OC & 27.32 & 17.82 & 9.13 & 2.60 \\
\hline $\mathrm{SO}_{4}^{2-}$ & 24.12 & 16.16 & 9.72 & 7.61 \\
\hline $\mathrm{NO}_{3}^{-}$ & 24.84 & 15.98 & 7.18 & 6.76 \\
\hline $\mathrm{Cl}^{-}$ & 5.82 & 3.04 & 2.08 & 1.56 \\
\hline $\mathrm{NH}_{4}{ }^{+}$ & 24.15 & 16.40 & 5.22 & 4.89 \\
\hline $\mathrm{Ca}^{2+}$ & 1.63 & 0.73 & 1.45 & 0.61 \\
\hline $\mathrm{K}^{+}$ & 1.20 & 0.80 & 1.19 & 0.61 \\
\hline $\mathrm{Mg}^{2+}$ & 0.24 & 0.09 & 0.23 & 0.15 \\
\hline $\mathrm{Na}^{+}$ & 0.86 & 0.46 & 0.64 & 0.32 \\
\hline $\mathrm{Si}$ & 13.38 & 6.02 & 6.29 & 5.49 \\
\hline $\mathrm{Al}$ & 5.04 & 2.22 & 1.78 & 2.21 \\
\hline K & 2.36 & 0.99 & 1.66 & 0.69 \\
\hline $\mathrm{Fe}$ & 1.18 & 0.37 & 1.04 & 0.29 \\
\hline $\mathrm{Pb}$ & 0.33 & 0.29 & 0.23 & 0.16 \\
\hline $\mathrm{Ba}$ & 0.04 & 0.02 & 0.03 & 0.03 \\
\hline Sn & 0.01 & 0.01 & - & - \\
\hline $\mathrm{Cd}$ & 0.01 & - & - & - \\
\hline Se & 0.01 & 0.01 & 0.01 & 0.01 \\
\hline As & 0.02 & 0.01 & 0.01 & 0.01 \\
\hline $\mathrm{Zn}$ & 0.42 & 0.29 & 0.24 & 0.15 \\
\hline $\mathrm{Cu}$ & 0.03 & 0.02 & 0.02 & 0.01 \\
\hline $\mathrm{Ni}$ & 0.01 & 0.01 & 0.01 & 0.01 \\
\hline $\mathrm{Mn}$ & 0.07 & 0.02 & 0.06 & 0.03 \\
\hline $\mathrm{Cr}$ & 0.02 & 0.02 & 0.02 & 0.03 \\
\hline $\mathrm{Ti}$ & 0.07 & 0.03 & 0.05 & 0.03 \\
\hline
\end{tabular}

The sum of the chemical components accounted for $69.6 \%$ and $64.7 \%$ of $\mathrm{PM}_{2.5}$ in the cold and warm periods, respectively. The mass closure gaps was found to exceed $40 \%$ in a previous study [36]. Tolocka et al. explained that the mass discrepancy was uncertainties stemming from analytic measurements [37]. To discuss the discrepancy, mass concentration was reconstructed based on measurements of the individual $\mathrm{PM}_{2.5}$ components. For the OC multiplier, a value of 1.4 was used in most mass balance studies [38]. The crustal $\mathrm{PM}_{2.5}$ was estimated using the sum of oxides algorithm $[39,40]$. The reconstructed results were 190.74 and $70.78 \mu \mathrm{g} \mathrm{m}^{-3}$, and the mass closure gaps were $11.1 \%$ and $11.8 \%$ in cold and warm periods, respectively. The reasons for the discrepancy might be explained as the uncertainty in measurements of chemical composition and $\mathrm{PM}_{2.5}$ mass, the use of an incorrect OC multiplication factor, and inaccuracies in estimates for the crustal component of $\mathrm{PM}_{2.5}$ mass. 

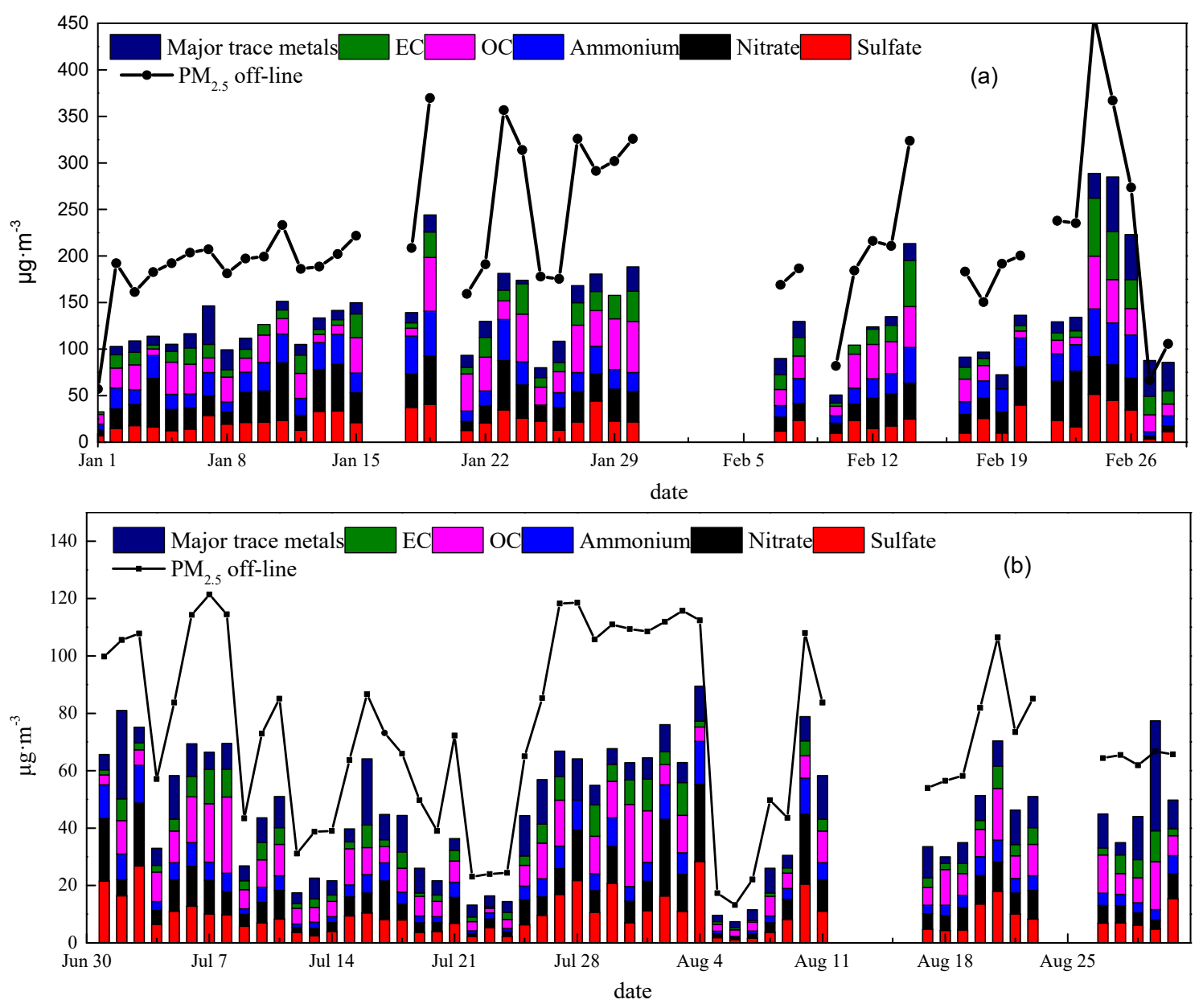

Figure 4. The time series of major $\mathrm{PM}_{2.5}$ components in (a) the cold period and (b) the warm period.

\subsection{Source Profiles of $P M_{2.5}$}

The $\mathrm{PM}_{2.5}$ source profile is referred to as the mass fraction of chemical components to particulate matter from a specific primary source [41]. A total of six $\mathrm{PM}_{2.5}$ source samples, including construction dust, coal combustion dust, metallurgical dust, road dust, fugitive dust and soil dust, were collected in Xingtai, as shown in Figure 5. Source profiles provide information about typical source tracers for source identification and quantification. The soil dust and fugitive dust share similar major components, $\mathrm{Si}, \mathrm{Ca}$ and $\mathrm{Fe}$ account for $60 \%$ and $63 \%$ in soil dust and fugitive dust, respectively. For road dust, $\mathrm{Si}, \mathrm{Ca}, \mathrm{Fe}$ and $\mathrm{OC}$, accounting for $78 \%$, are considered the typical tracers. For metallurgical dust, Fe plays the most important role, accounting for $31 \%$, followed by $\mathrm{SO}_{4}{ }^{2-}(20 \%)$ and $\mathrm{Si}(11 \%)$. $\mathrm{Si}, \mathrm{Ca}, \mathrm{OC}$, and EC are four important tracers for coal combustion. Ca accounts for the most in construction dust, about $26 \%$, which is significantly higher than others. 

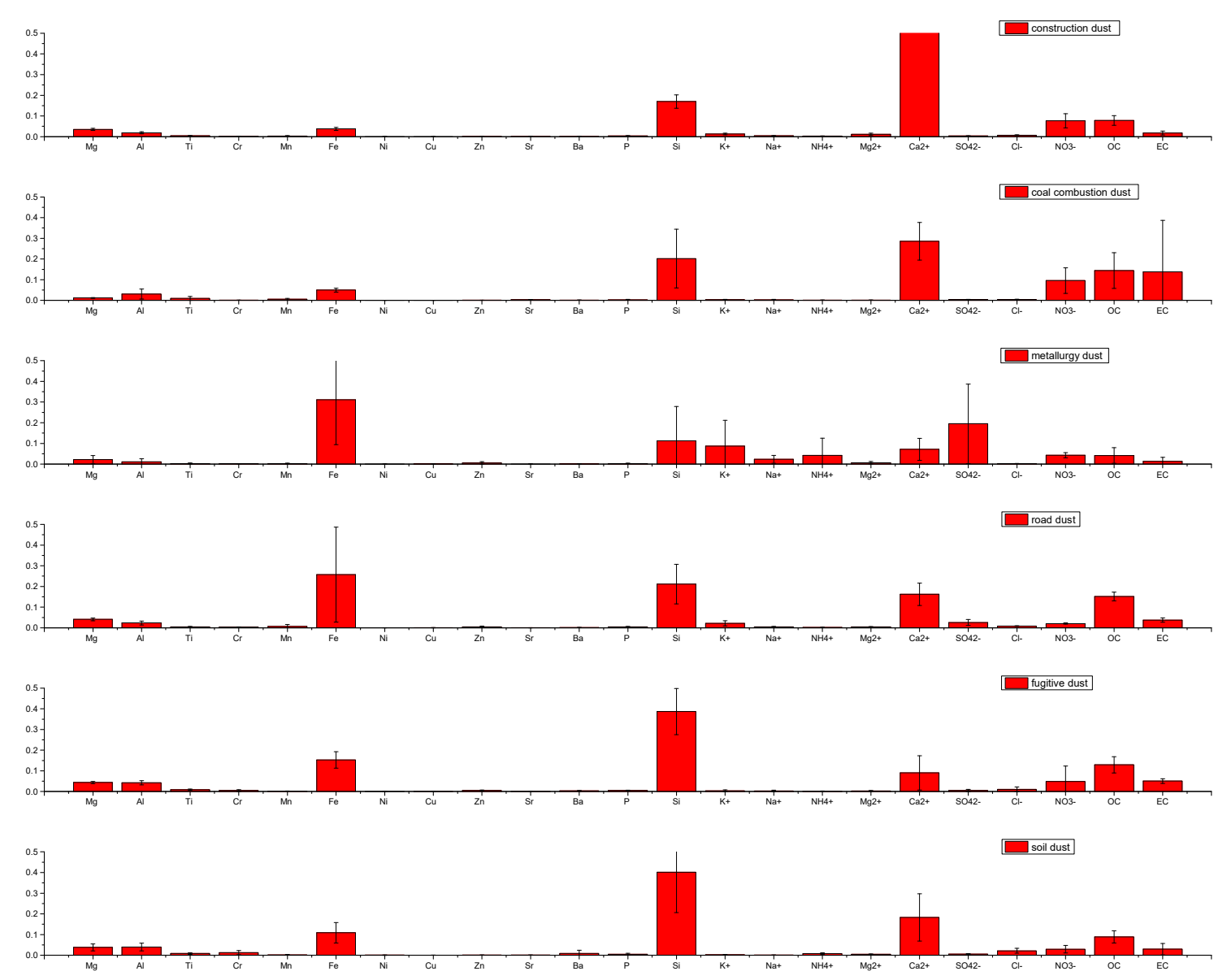

Figure 5. $\mathrm{PM}_{2.5}$ source profiles in Xingtai.

\subsection{Source Apportionment of $P M_{2.5}$}

The contribution of emission sources to ambient $\mathrm{PM}_{2.5}$ in Xingtai during the cold and warm periods, as well as the overall average, are shown in Table 2. Source apportionment results demonstrated that the major sources of $\mathrm{PM}_{2.5}$ were coal combustion dust, secondary sulfate, secondary nitrate and vehicle exhaust dust. The contribution of coal combustion dust varied from $17.4 \%$ to $28.4 \%$, secondary sulfate ranged from $20.8 \%$ to $22.5 \%$, secondary nitrate from $17.0 \%$ to $21.9 \%$ and the contribution of vehicle exhaust ranged from $11.8 \%$ to $14.8 \%$. The contribution of coal combustion played an important role in the formation of $\mathrm{PM}_{2.5}$; the control of coal combustion is the primary task of the control of $\mathrm{PM}_{2.5}$ in Xingtai. The contribution of secondary sulfate and secondary nitrate accounted for a large proportion. According to the principle of secondary particle generation, coal combustion, industrial activities and vehicle exhaust not only contribute a large number of primary $\mathrm{PM}_{2.5}$, but also produce a large number of gaseous precursors such as sulfur dioxide and nitrogen oxides. These gaseous pollutants undergo a photochemical reaction in the atmosphere, generating a large amount of secondary sulfate and secondary nitrate. Thus, controlling sulfur dioxide and nitrogen oxides emissions is the key to reducing secondary $\mathrm{PM}_{2.5}$. Additionally, fugitive dust, soil dust and construction dust accounted for $9.7 \%, 3.4 \%$, and $1.6 \%$ in $\mathrm{PM}_{2.5}$ source contribution, respectively. 
Table 2. Chemical mass balance source apportionment of ambient $\mathrm{PM}_{2.5}$ in Xingtai in the cold and warm period, and the overall average values.

\begin{tabular}{ccccccc}
\hline \multirow{2}{*}{ Source } & \multicolumn{2}{c}{ Cold Period } & \multicolumn{2}{c}{ Warm Period } & \multicolumn{2}{c}{ Average } \\
\cline { 2 - 7 } & $\mathbf{( \% )}$ & $\mu \mathbf{g ~ m}^{-3}$ & $\mathbf{( \% )}$ & $\boldsymbol{\mu g ~ \mathbf { ~ m } ^ { - 3 }}$ & $\mathbf{( \% )}$ & $\boldsymbol{\mu g ~ m}^{-3}$ \\
\hline Fugitive dust & $6.7 \%$ & $14.4 \pm 4.3$ & $10.6 \%$ & $8.6 \pm 3.1$ & $9.7 \%$ & $14.3 \pm 5.3$ \\
Soil dust & $2.8 \%$ & $6.0 \pm 2.1$ & $3.6 \%$ & $2.9 \pm 1.1$ & $3.4 \%$ & $5.0 \pm 2.4$ \\
Metallurgy dust & $0.7 \%$ & $1.6 \pm 2.7$ & $2.3 \%$ & $1.9 \pm 1.3$ & $1.6 \%$ & $2.3 \pm 2.4$ \\
Coal combustion dust & $28.4 \%$ & $60.9 \pm 25.9$ & $17.4 \%$ & $14.1 \pm 6.2$ & $24.4 \%$ & $36.1 \pm 14.7$ \\
Construction dust & $5.0 \%$ & $10.7 \pm 4.8$ & $4.9 \%$ & $4.0 \pm 1.7$ & $5.5 \%$ & $8.1 \pm 2.9$ \\
Secondary sulfate & $20.8 \%$ & $44.6 \pm 19.6$ & $22.5 \%$ & $18.2 \pm 9.3$ & $22.2 \%$ & $32.9 \pm 18.3$ \\
Secondary nitrate & $21.9 \%$ & $46.9 \pm 18.3$ & $17.0 \%$ & $13.8 \pm 6.7$ & $18.4 \%$ & $27.2 \pm 16.1$ \\
Vehicle exhaust dust & $11.8 \%$ & $25.4 \pm 10.8$ & $14.8 \%$ & $12.0 \pm 5.9$ & $12.4 \%$ & $18.3 \pm 12.2$ \\
Unknown source & $1.8 \%$ & - & $6.9 \%$ & - & $2.6 \%$ & - \\
\hline
\end{tabular}

There were differences in source apportionment of ambient $\mathrm{PM}_{2.5}$ during different periods. The contribution of coal combustion dust for $\mathrm{PM}_{2.5}$ in cold period was higher than in warm period. It was indicated that coal combustion must be controlled, especially in cold period. Additionally, the contributions of fugitive dust and vehicle exhaust for $\mathrm{PM}_{2.5}$ in the cold period were lower than in the warm period. It was indicated that fugitive dust and vehicle exhaust must be controlled in the warm period.

Several source apportionment studies have been performed on $\mathrm{PM}_{2.5}$ in the Beijing-Tianjin-Hebei region. Huang et al. [42] demonstrated that secondary inorganic aerosol was the largest $\mathrm{PM}_{2.5}$ source in this region, accounting for $29.2 \%, 36.4 \%, 40.5 \%$, and $45.1 \%$ of the $\mathrm{PM}_{2.5}$ mass in Tianjin Shijiazhuang, Beijing and Xinglong, respectively. This result was similar with that in Xingtai (40.6\%). It was different in the second largest $\mathrm{PM}_{2.5}$ source: The second-largest $\mathrm{PM}_{2.5}$ source was motor vehicle exhaust in Beijing, Tianjin and Shijiazhuang, whereas coal combustion was the second largest source in Xingtai (24.4\%), especially for the cold period. It should be noted that the coal combustion source contributed significantly higher than the three cities in Xingtai.

In conclusion, it can be observed that contributions of coal combustion to ambient $\mathrm{PM}_{2.5}$ were much higher compared to other sources, which was probably attributable to more industrial activities, as well as the presence coal-fired power plants in Xingtai. Furthermore, bulk coal combustion, as a residential energy in winter, was an essential contributor. Correspondingly, it can be concluded that the emissions of ambient $\mathrm{PM}_{2.5}$ sources are relatively higher during the winter than other seasons. It was worth noting that regional transport also influenced haze pollution in the Beijing-Tianjin-Hebei region [42], and in this study due to the lower wind speed, particularly in the cold period, the slow and near-ground air masses originating from Shijiazhuang and Handan could have resulted in stagnant conditions, under which precursors from local emissions and those transported in could constitute a significant contribution to Xingtai's ambient $\mathrm{PM}_{2.5}$.

\subsection{Emission Control Measures}

$\mathrm{PM}_{2.5}$ pollution in Xingtai was still among in the top ten polluted cities in China. Source apportionment results, summarized above, have provided scientific evidence for formulating effective emission control measures of Xingtai's $\mathrm{PM}_{2.5}$. Based on source apportionment results, emission reductions in coal combustion, secondary inorganic aerosol, vehicle exhaust and fugitive dust can help achieve $\mathrm{PM}_{2.5}$ reduction targets and diminishing environmental, economic and health costs of $\mathrm{PM}_{2.5}$ pollution. $\mathrm{PM}_{2.5}$ emission control measures in Xingtai should predominantly focus on reducing coal consumption, which not merely lead to emission reduction of primary $\mathrm{PM}_{2.5}$, but also decrease gaseous precursors emissions of secondary $\mathrm{PM}_{2.5}$ (such as $\mathrm{SO}_{2}, \mathrm{NOx}, \mathrm{NH}_{3}$, and VOCs). Some control measures of coal combustion should be adopted by local policy makers and implemented by local governments in order to improve Xingtai's ambient air quality. For instance, coal-fired power plant should be introduced with ultra-low emissions, industrial coal-fired boilers should be upgraded, bulk coals 
should be replaced with clean energy sources in the countryside, and industrial emission standards of pollutants should be tightened. Moreover, based on the principle of "classification treatment and collaborative control", the following control measures are expected to reduce emissions of both primary and secondary $\mathrm{PM}_{2.5}$. For example, (1) controlling fugitive (road, construction and soil dust) emissions with actions such as sprinkling the roads regularly, covering all vehicles which transporting muck, and increasing urban green areas; (2) halting operations of heavy polluters; (3) punishing vehicles that violate emission standards; and (4) upscaling fuel quality.

In recent years, the importance of VOCs to secondary $\mathrm{PM}_{2.5}$ pollution has been recognized in autumn and winter, but the corresponding emission control measures about VOCs are not yet well defined. In order to improve Xingtai's urban air quality, stringent controls on VOCs emissions from coal combustion, industrial production and vehicle emissions should be considered by local policy makers. Other cities in Hebei Province, for example, Shijiazhuang, Tangshan, and Handan, etc., are also experiencing severe $\mathrm{PM}_{2.5}$ pollution. Based on current status of $\mathrm{PM}_{2.5}$ pollution in Hebei Province, regional transport is demonstrated to be another important contributor to the formation of $\mathrm{PM}_{2.5}$ [43]. Similar emission control measures can be considered to be implemented by other local government, which is imperative for cleaning the air in Beijing-Tianjin-Hebei (BTH) and its surrounding areas.

\section{Conclusions}

In 2014, annual $\mathrm{PM}_{2.5}$ mass concentrations in Xingtai were $130 \mu \mathrm{g} \mathrm{m}^{-3}$, which was 3.7 times higher than Chinese NAAQS value for $\mathrm{PM}_{2.5}\left(35 \mu \mathrm{g} \mathrm{m}{ }^{-3}\right)$. During cold and warm periods, Xingtai's $\mathrm{PM}_{2.5}$ mass concentrations (off-line data) were 214.53 and $81.43 \mu \mathrm{g} \mathrm{m}^{-3}$, respectively, whose chemical components were mainly dominated by $\mathrm{OC}, \mathrm{EC}, \mathrm{SO}_{4}{ }^{2-}, \mathrm{NO}_{3}{ }^{-}$, and $\mathrm{NH}_{4}{ }^{+}$. Eight major source categories of ambient $\mathrm{PM}_{2.5}$ were identified by the $\mathrm{CMB}$ model. As a result, coal combustion was the biggest contributor, followed by secondary sulfate, secondary nitrate, vehicle exhaust dust, fugitive dust, construction dust soil dust and metallurgy dust. Based on source apportionment results, emission control measures in coal combustion, industrial production, motor vehicle and fugitive dust were proposed, such as ultra-low emissions in coal-fired power plants and industrial boilers, controlling fugitive emissions, tightening emission standards of pollutants and upscaling fuel quality. The implementation of emission control measures presented in this study was expected to help achieve positive benefits on improving Xingtai's air quality.

Author Contributions: Conceptualization, S.W. and F.C.; methodology, J.H. and H.Z.; data analysis and discussion of the results, J.H. and H.W.; sample collection and data determination and validation, J.Z. and M.Z.; writing — original draft preparation, J.H.; writing—review and editing, H.Z., S.W. and F.C.; All of the authors were involved in the preparation, revision and review of the manuscript.

Funding: This work was supported by an Environmental Protection Public Welfare Scientific Research Project, Ministry of Environmental Protection of the People's Republic of China (No. 201509002); the Special fund of State Key Joint Laboratory of Environment Simulation and Pollution Control (15K08ESPCT); Scientific Research Foundation for the Returned Overseas Chinese Scholars, State Education Ministry; and the State Key Laboratory of Environmental Criteria and Risk Assessment, Chinese Research Academy of Environmental Science (SKLECRA201747), National Science and Technology Support Program (No. 2014BAC06B01).

Acknowledgments: The authors would like to thank the Bureau of Ecology and Environment of Xingtai for administrative support of this study and thank the Environmental Monitor Center of Xingtai for technical support of this study.

Conflicts of Interest: The authors declare no conflict of interest.

\section{References}

1. Zhang, R.; Jing, J.; Tao, J.; Hsu, S.C.; Wang, G.; Cao, J.; Lee, S.L.; Zhu, L.; Chen, Z.; Zhao, Y.; Shen, Z. Chemical characterization and source apportionment of $\mathrm{PM}_{2.5}$ in Beijing: seasonal perspective. Atmos. Chem. Phys. 2013, 13, 7053-7074. [CrossRef]

2. Zhang, H.; Wang, S.; Hao, J.; Wang, X.; Wang, S.; Chai, F.; Li, M. Air pollution and control action in Beijing. J. Clean. Prod. 2016, 112, 1519-1527. [CrossRef] 
3. Tao, J.; Gao, J.; Zhang, L.; Zhang, R.; Che, H.; Zhang, Z.; Lin, Z.; Jing, J.; Cao, J.; Hsu, S.C. PM 2.5 pollution in a megacity of southwest China: Source apportionment and implication. Atmos. Chem. Phys. 2014, 14, 8679-8699. [CrossRef]

4. Maji, K.; Dikshit, A.; Arora, M.; Deshpande, A. Estimating premature mortality attributable to $\mathrm{PM}_{2.5}$ exposure and benefit of air pollution control policies in China for 2020. Sci. Total Environ. 2018, 612, $683-693$. [CrossRef] [PubMed]

5. Yang, L.; Cheng, S.; Wang, X.; Nie, W.; Xu, P.; Gao, X.; Yuan, C.; Wang, W. Source identification and health impact of $\mathrm{PM}_{2.5}$ in a heavily polluted urban atmosphere in China. Atmos. Environ. 2013, 75, 65-269. [CrossRef]

6. Lim, S.S.; Vos, T.; Flaxman, A.D.; Danaei, G.; Shibuya, K.; Adair-Rohani, H.; AlMazroa, M.A.; Amann, M.; Anderson, P.H.R.; Andrews, K.G.; et al. A comparative risk assessment of burden of disease and injury attributable to 67 risk factors and risk factor clusters in 21 regions, 1990-2010: A systematic analysis for the Global Burden of Disease Study 2010. Lancet 2013, 380, 2224-2260. [CrossRef]

7. Zhang, H.; Hu, J.; Qi, Y.; Li, C.; Chen, J.; Wang, X.; He, J.; Wang, X.; Hao, J.; Zhang, L.; et al. Emission characterization, environmental impact, and control measure of $\mathrm{PM}_{2.5}$ emitted from agricultural crop residue burning in China. J. Clean. Prod. 2017, 149, 629-635. [CrossRef]

8. Ministry of Ecology and Environment of the People's Republic of China. 2012. Available online: http:/ / kjs.mee.gov.cn/hjbhbz/bzwb/dqhjbh/dqhjzlbz/201203/t20120302_224165.shtml (accessed on 31 December 2018).

9. Ministry of Ecology and Environment of the People's Republic of China. 2014. Available online: http: / / www.mee.gov.cn/hjzl/zghjzkgb/lnzghjzkgb / (accessed on 31 December 2018).

10. Ministry of Ecology and Environment of the People's Republic of China. 2015. Available online: http: / / www.mee.gov.cn/hjzl/zghjzkgb/lnzghjzkgb / (accessed on 31 December 2018).

11. Chow, J.C.; Watson, J.G.; Lowenthal, D.H.; Chen, L.W.A.; Zielinska, B.; Mazzoleni, L.R.; Magliano, K.L. Valuation of organic markers for chemical mass balance source apportionment at the Fresno Supersite. Atmos. Chem. Phys. 2007, 7, 1741-1754. [CrossRef]

12. Watson, J.G.; Chen, L.W.A.; Chow, J.C.; Doraiswamy, P.; Lowenthal, D.H. Source apportionment: findings from the U.S. supersites program. J. Air Waste Manag. Assoc. 2008, 58, 265-288. [CrossRef] [PubMed]

13. Shi, G.L.; Tian, Y.Z.; Zhang, Y.F.; Ye, W.Y.; Li, X.; Tie, X.X.; Feng, Y.C.; Zhu, T. Estimation of the concentrations of primary and secondary organic carbon in ambient particulate matter: Application of the CMB-Iteration method. Atmos. Environ. 2011, 45, 5692-5698. [CrossRef]

14. Zhang, Y.; Cai, J.; Wang, S.; He, K.; Zheng, M. Review of receptor-based source apportionment research of fine particulate matter and its challenges in China. Sci. Total Environ. 2017, 586, 917-929. [CrossRef] [PubMed]

15. Chow, J.C.; Watson, J.G.; Houck, J.E.; Pritchett, L.C.; Fred Rogers, C.; Frazier, C.A.; Egami, R.T.; Ball, B.M. A laboratory resuspension chamber to measure fugitive dust size distributions and chemical compositions. Atmos. Environ. 1994, 28, 3463-3481. [CrossRef]

16. Carvacho, O.F.; Ashbaugh, L.L.; Brown, M.S.; Flocchini, R.G. Measurement of $\mathrm{PM}_{2.5}$ emission potential from soil using the uc davis resuspension test chamber. Geomorphology 2004, 59, 75-80. [CrossRef]

17. Bi, X.; Feng, Y.; Wu, J.; Wang, Y.; Zhu, T. Source apportionment of $\mathrm{PM}_{10}$ in six cities of northern China. Atmos. Environ. 2007, 41, 903-912. [CrossRef]

18. Hsu, S.C.; Liu, S.C.; Huang, Y.T.; Lung, S.C.C.; Tsai, F.; Tu, J.Y.; Kao, S.J. A criterion for identifying Asian dust events based on Al concentration data collected from northern Taiwan between 2002 and early 2007. J. Geophys. Res. Atmos. 2008, 113, D18306. [CrossRef]

19. Hsu, S.C.; Liu, S.C.; Kao, S.J.; Jeng, W.L.; Huang, Y.T.; Tseng, C.M.; Tsai, F.; Tu, J.Y.; Yang, Y. Water-soluble species in the marine aerosol from the northern South China Sea: High chloride depletion related to air pollution. J. Geophys. Res. Atmos. 2007, 112, D19304. [CrossRef]

20. Hsu, S.C.; Liu, S.C.; Tsai, F.; Engling, G.; Lin, I.I.; Chou, C.K.C.; Kao, S.J.; Lung, S.C.C.; Chan, C.Y.; Lin, S.C. High wintertime particulate matter pollution over an offshore island (Kinmen) off southeastern China: An overview. J. Geophys. Res. Atmos. 2010, 115, 1383-1392. [CrossRef]

21. Tian, S.; Pan, Y.; Liu, Z.; Wen, T.; Wang, Y. Size-resolved aerosol chemical analysis of extreme haze pollution events during early 2013 in urban Beijing, China. J. Hazard. Mater. 2014, 279, 452-460. [CrossRef] [PubMed] 
22. Liu, B.S.; Song, N.; Dai, Q.L.; Mei, R.B.; Sui, B.H.; Bi, X.H.; Feng, Y.C. Chemical composition and source apportionment of ambient $\mathrm{PM}_{2.5}$ during the nonheating period in Taian, China. Atmos. Res. 2016, 170, $23-33$. [CrossRef]

23. Chow, J.C.; Watson, J.G.; Chen, L.W.A.; Chang, M.C.O.; Robinson, N.F.; Trimble, D.; Kohl, S. The IMPROVE_A temperature protocol for thermal/optical carbon analysis: maintaining consistency with a long term database. J. Air Waste Manag. Assoc. 2007, 57, 1014-1023. [CrossRef] [PubMed]

24. Zhang, Y.L.; Perron, N.; Ciobanu, V.G.; Zotter, P.; Minguillon, M.C.; Wacker, L.; Prevot, A.S.H.; Baltensperger, U.; Szidat, S. On the isolation of OC and EC and the optical strategy of radiocarbon-based source apportionment of carbonaceous aerosols. Atmos. Chem. Phys. 2012, 12, 10841-10856. [CrossRef]

25. Ke, L.; Ding, X.; Tanner, R.L.; Schauer, J.J.; Zheng, M. Source contributions to carbonaceous aerosols in the Tennessee Valley Region. Atmos. Environ. 2007, 41, 8898-8923. [CrossRef]

26. Stone, E.A.; Snyder, D.C.; Sheesley, R.J.; Sullivan, A.P.; Weber, R.J.; Schauer, J.J. Source apportionment of fine organic aerosol in Mexico City during the MILAGRO experiment 2006. Atmos. Chem. Phys. 2008, 8, 1249-1259. [CrossRef]

27. Kleeman, M.J.; Riddle, S.G.; Robert, M.A.; Jakober, C.A.; Fine, P.M.; Hays, M.D.; Schauer, J.J.; Hannigan, M.P. Source apportionment of fine $\left(\mathrm{PM}_{1.8}\right)$ and ultrafine $\left(\mathrm{PM}_{0.1}\right)$ airborne particulate matter during a severe winter pollution episode. Environ. Sci. Technol. 2009, 43, 272-279. [CrossRef] [PubMed]

28. Yin, J.; Harrison, R.M.; Chen, Q.; Rutter, A.; Schauer, J.J. Source apportionment of fine particles at urban background and rural sites in the UK atmosphere. Atmos. Environ. 2010, 44, 841-851. [CrossRef]

29. Perrone, M.G.; Larsen, B.R.; Ferrero, L.; Sangiorgi, G.; Gennaro, G.D.; Udisti, R.; Zangrando, R.; Gambaro, A.; Bolzacchini, E. Sources of high $\mathrm{PM}_{2.5}$ concentrations in Milan, Northern Italy: Molecular marker data and CMB modelling. Sci. Total Environ. 2012, 414, 343-355. [CrossRef] [PubMed]

30. Villalobos, A.M.; Barraza, F.; Jorquera, H.; Schauer, J.J. Chemical speciation and source apportionment of fine particulate matter in Santiago, Chile, 2013. Sci. Total Environ. 2015, 512-513, 133-142. [CrossRef] [PubMed]

31. Henry, R.C.; Lewis, C.W.; Hopke, P.K.; Williamson, H.J. Review of receptor model fundamentals. Atmos. Environ. 1984, 18, 1507-1515. [CrossRef]

32. Wu, L.; Shen, J.D.; Feng, Y.C.; Bi, X.H.; Jiao, L.; Liu, S.X. Source Apportionment of Particulate Matters in Different Size Bins during Hazy and Non-Hazy Episodes in Hangzhou City. Res. Environ. Sci. 2014, 27, 373-381.

33. Cao, J.J.; Chow, J.C.; Watson, J.G.; Wu, F.; Han, Y.M.; Jin, Z.D.; Shen, Z.X.; An, Z.S. Size-differentiated source profiles for fugitive dust in the Chinese Loess Plateau. Atmos. Environ. 2008, 42, 2261-2275. [CrossRef]

34. Shuang, D.; Shi, Y.; Yu, L.; Chen, Z.; Wang, X.; Cao, Q.; Li, S.; Fan, Z. Emission characteristics of Cd, Pb and $\mathrm{Mn}$ from coal combustion: Field study at coal-fired power plants in China. Fuel Process. Technol. 2014, 126, 469-475.

35. Wang, Y.F.; Huang, K.L.; Li, C.T.; Mi, H.H.; Luo, J.H.; Tsai, P.J. Emissions of fuel metals content from a diesel vehicle engine. Atmos. Environ. 2003, 37, 4637-4643. [CrossRef]

36. Jansen, J.J.; Edgerton, E.S.; Hansen, D.A.; Hartsell, B.E. Sampling Artifacts in the Federal Reference Method for PM2.5. 2002. Available online: www.atmospheric-research.com (accessed on 31 December 2018).

37. Tolocka, M.; Solomon, P.; Mitchell, W.; Norris, G.; Gemmill, D.; Wiener, R.; Vanderpool, R.; Homolya, J.; Rice, J. East versus West in the US: Chemical Characteristics of $\mathrm{PM}_{2.5}$ during the Winter of 1999. Aerosol Sci. Technol. 2001, 34, 88-96. [CrossRef]

38. Turpin, B.; Lim, H.-J. Species Contributions to PM2.5 Mass Concentrations: Revisiting Common Assumptions for Estimating Organic Mass. Aerosol Sci. Technol. 2001, 35, 602-610. [CrossRef]

39. Malm, W.C.; Gebhart, K.A.; Molenar, J.; Cahill, T.; Eldred, R.; Huffman, D. Examining the relationship between atmospheric aerosols and light extinction at Mount Rainier and North Cascades National Parks. Atmosp. Environ. 1994, 28, 347-360. [CrossRef]

40. Malm, W.C.; Sisler, J.F.; Huffman, D.; Eldred, R.A.; Cahill, T.A. Spatial and Seasonal Trends in Particle Concentration and Optical Extinction in the United-States. J. Geophys. Res. Atmos. 1994, 99, 1347-1370. [CrossRef]

41. Chow, J.C.; Watson, J.G.; Kuhns, H.; Etyemezian, V.; Low-enthal, D.H.; Crow, D.; Kohl, S.D.; Engelbrecht, J.P.; Green, M.C. Source profiles for industrial, mobile, and areasources in the big bend regional aerosol visibility and observational study. Chemosphere 2004, 54, 185-208. [CrossRef] [PubMed] 
42. Huang, X.; Liu, Z.; Liu, J.; Hu, B.; Wen, T.; Tang, G.; Zhang, J.; Wu, F.; Ji, D.; Wang, L.; et al. Chemical characterization and source identification of $\mathrm{PM}_{2.5}$ at multiple sites in the Beijing-Tianjin-Hebei region, China. Atmos. Chem. Phys. 2017, 17, 12941-12962. [CrossRef]

43. Li, X.; Zhang, Q.; Zhang, Y.; Zheng, B.; Wang, K.; Chen, Y.; Wallington, T.J.; Han, W.; Shen, W.; Zhang, X.; et al. Source contributions of urban $\mathrm{PM}_{2.5}$ in the Beijing-Tianjin-Hebei region: Changes between 2006 and 2013 and relative impacts of emissions and meteorology. Atmos. Environ. 2015, 123, 229-239. [CrossRef]

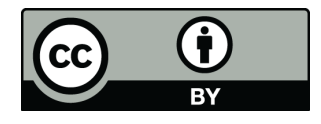

(C) 2019 by the authors. Licensee MDPI, Basel, Switzerland. This article is an open access article distributed under the terms and conditions of the Creative Commons Attribution (CC BY) license (http:/ / creativecommons.org/licenses/by/4.0/). 